811.163.41'373.21

https://doi.org/10.18485/sj.2020.25.1.41

ТАТЈАНА Г. ТРАЈКОВИТ ${ }^{*}$

Универзитет у Нишу

Филозофски факултет
Оригинални научни рад

Примљен: 15. 10. 2019.

Прихваћен: 15. 01. 2020.

\title{
ХОДОНИМИ НИША ТОПОНИМСКЕ МОТИВАЦИЈЕ ${ }^{* *}$
}

\begin{abstract}
У раду је представљена ономастичка анализа нишких ходонима мотивисаних топонимом. Примењена је корпусна, аналитичка, дескриптивна и компаративна метода с циљем да се утврди које врсте топонима учествују као мотиватори у номинацији нишких улица. Ходоними су тумачени и из структураног угла са циљем да се одреди најпродуктивнија форма. Квантитативном обрадом грађе дошло се до закључака о фреквентности појединих ходонимских типова топонимске мотивације. Мотивисаност ојконимима са подручја Србије показала је велику фреквентност, док је форма исказана присвојним придевом најчешће коришћена у нишкој ходонимији.
\end{abstract}

Кључне речи: српски језик, ономастика, ходонимија, топонимија, Ниш.

\section{1. УВОД}

1.1. Нишка ходонимија до сада није системски обрађивана из ономастичког угла. Овај рад посвећен је нишким ходонимима у чијем су именовању као мотивацијски елемент учествовали топоними у ширем смислу (анојконими и

*tatjana.trajkovic@filfak.ni.ac.rs

** Рад је настао у оквиру пројеката: Дијалектолошка истраживања српског језичког простора, који у целини финансира Министарство просвете, науке и технолошког развоја Републике Србије; Српски језик некад и сад: лингвистичка истраживања Филозофски факултет Универзитета у Нишу. 
ојконими). Извршена је њихова мотивацијска и структурна анализа са циљем да се ходоними града Ниша што прецизније језички обраде, а имајући у виду да су ходоними ономастичке јединице које чине саставни део историјског, културног и језичког идентитета једног насеља, али и читавог народа. ${ }^{1}$

1.2. Мали број српских лингвиста бавио се ходонимима у Србији. Са радом првенцем ове врсте код нас истиче се Милица Лађевић, која је обрађивала урбониме града Панчева из структурно-типолошког и мотивационо-семантичког угла (Лађевић 1984). Новом Саду такође је посвећен рад из урбане ономастике ауторке Виолете Ракић, која је тумачила структуру, мотивисаност и преименовања новосадских улица (Ракић 2009). Владимир Поломац је анализирао структуру београдских ходонима са антропонимом у основи (Поломац 2013). Митра Рељић је свој рад посветила ходонимима Косовске Митровице и у њему представила српскојезичке и албанојезичке ходониме тумачећи мотивациони аспект обеју страна, који се прилично разликују (Рељић 2016).

1.3. Ниш је један од највећих градова Србије. Заузима површину од

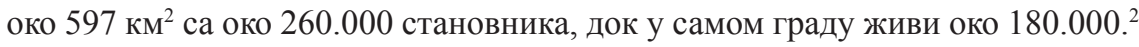
Град се из деценије у деценију просторно ширио и тај процес и даље траје. Административно овај град је подељен на пет општина: Медијана, Палилула, Пантелеј, Црвени крст и Нишка Бана. Међутим, поред званичне просторне поделе града, Ниш има незванична насеља народних имена, која су у чешћој употреби него имена општина. То су имена данашњих такозваних градских четврти, односно, како се некада говорило, махала. Нека од ових имена су старија, а нека су из новијег времена: Јагодин мала, Јоргован мала, Београд мала, Шећер мала, Ледена стена, Бубањ, Кичево, Маргер, Расадник, Црвени певаи, Трошарина, Дурлан, Дуваниште, Беверли хилс итд. Савремено стање градске администрације показује да овај град има 1.463 улице и трга. Прва имена улица Ниш је највероватније добио у последњим деценијама 19. века: Господска, Краљева, Обреновићева, Страхинића Бана, Гимназијска, Школска, Душанова, Обилићев венаи, Трг краља Милана итд. Имена улица су се стално додавала, али су се, у складу са друштвено-политичким променама, мењала она постојећа, пратећи на тај начин актуелна очекивања владајућег дела друштва. Таквим изменама нарочито су склони ходоними хонорификацијске етиологије. Наиме, имена истакнутих суграђана, историјских, културних, научних и других личности нису у свим друштвеним околностима била добродошла, те су преименовања улица пратећи моменат политичких и сличних обрта у

${ }^{1}$ Доступност грађе за овај рад олакшана је захваљујући скоро објављеној монографији Улице и тргови града Ниша (Станисављевић/Димитријевић 2018), у којој су на енциклопедијски начин изнети бројни подаци и занимљивости у вези са именовањима нишких насеља, улица, тргова.

${ }^{2}$ Подаци су преузети са сајтова https://sr.wikipedia.org/Ниш и http://www.ni.rs:80/licnakarta-grada.html. Приступљено 10. 8. 2018. 
некој заједници. У овом раду неће бити речи о оваквим изменама у нишкој ходонимији. Ономастичка анализа биће посвећена оним ходонимима у чијој се структури налази неки топоним. Применом корпусне, аналитичке, дескриптивне и компаративне методе биће утврђено која врста топонима улази у састав имена улица Ниша. Квантитативном обрадом грађе доћи ће се до података о фреквентности појединих ходонимских типова топонимске мотивације.

1.4. Од укупног броја нишких улица, 380 је топонимске мотивације, што чини $25,97 \%$ целокупног нишког ходонимског инвентара. У оквиру овог броја утврђена је заступљеност појединих топонимских типова који су учествовали у именовању нишких улица. Ту су се нашли: ојконими (астионими и комоними), ороними, хороними, хидроними, имена градских четврти, микротопоними, имена манастира и цркава, имена острва. Приликом избора термина за поједине врсте топонима наметнуо се проблем неуједначености ономастичке терминологије у словенском свету, па и у српском језику. За ову прилику консултовани су речник руске ономастичке терминологије Н. В. Подољске и својеврсни речник словенске ономастичке терминологије (Безлај 1983). Међутим, ни то није било тако лако примењивати, о чему је већ писао М. Шћепановић (1997). Сагледавањем садржине књиге Основен систем и терминологија на словенската ономастика (Безлај 1983) и упоређивањем са српском ономастичком праксом дошао је до закључка да је српска терминологија почела да се кристалише једино радовима наших ономастичара којима се дошло до тога да је наша терминологија интернационална, што је важно јер „олакшава научну комуникацију”, али и национална, што се одражава на морфолошком и творбеном плану (Шћепановић 1997: 220).

1.5. Принцип одабира термина за потребе овог рада био је да се, наравно, узме у обзир општа терминологија, а што се тиче даљих именовања у оквиру постојећег топономастичког језгра, водило се рачуна да се не иде ка уситњавању уколико то није неопходно. У случају да се укаже потреба за сачињавањем групе одређених топонима с обзиром на створено заједничко онимијско поље, именовање ће бити према општеприхваћеној терминологији. Поштујући начело да терминологију не би требало претерано оптерећивати појединачним називима (в. предговор у Безлај 1983: 7-54), неке групе топонима именоваће се дескриптивно. То значи да ће постојати група ојконима (имена насељених места), али и да ће она обухватати две подгрупе које су се показале као веома значајне у именовању нишких улица: астионими (имена градова) и комоними (имена села) будући да су ови термини заживели у домаћој ономастичкој литератури. У случају хидронима, овај термин ће се односити на сваку водену површину: реке, језере, мора. Иако имам у виду постојање појединачних термина: потамоними (имена река), пелагоними (имена мора), лимноними (имена језера), сматрам да је даља подела непотребна. Имена градских четврти, имена манастира и иркава и имена острва остаће описна. Постоје термини 
који се тичу ових врста топонима, али се они нису сасвим одомаћили у српској ономастици. Руска ономастика за градске четврти као и друге делова града предвиђа синтагму городской хороним (Подољска 1978: 160). Имена цркава и манастира могла би се означити термином еклезионим (Подољска 1978: 164). За имена острва руски речник предвиђа термин инсулоним, који се, додуше, не јавља као одредничка реч у речнику, већ само у списку на крају речника под називом Предметно-терминологический указатель (Подољска 1978: 197-198), али се истиче да се ради о термину из француског језика.

\section{2. ИСТРАЖИВАњЕ - ОПИС И РЕЗУЛТАТИ}

2.1. На почетку описа истраживања изнета је грађа разврстана према групама и подгрупама топонима којима су ходоними мотивисани, чији је редослед одређен бројношћу ходонима у којима се налази као мотивациони елемент. Основних мотивационих група има осам: ојконими, ороними, хидроними, хороними, имена градских четври, микротопоними, имена манастира и иркава, имена острва. Након овог дела следи дескрипција заступљености топонимских типова према врсти топонима и према географском пореклу. Мањи одељак је посвећен тумачењу структуре обрађене грађе, које је усмерено ка језичкој форми ходонима. Резултати истраживања представљени у дијаграмима.

2.2. Ојконими су се показали као најфреквентнија мотивациона група у нишким ходонимима. Ови ходоними подељени су на подгрупе са астионимом и комонимом у саставном делу имена.

А) Ходоними са астионимом у саставном делу имена: Алексиначка, Аранђеловачка, Бањалучка, Бањска, Барска, Белопаланачка, Београдска, Бечејска, Билећка, Битољска, Блачка, Бледска, Бојничка, Бокељска, Борска, Бохињска, Бугојничка, Ваљевска, Варваринска, Великотрновска, Винковачка, Вишеградска, Власотиначка, Вршачка, Вучитрнска, Врањанска, Гачинханска, Гламочка, Гюиланска, Голубачка, Гостиварска, Грделичка, Дебарска, Деспотовачка, Димитровградска, Дрварска, Дубровачка, Бевђелијска, Загребачка, Зајечарска, Звечанска, Иванградска, Земунска, Јагодинска, Карловачка, Кичевачка, Кладовска, Книнска, Кьажевачка, Колашинска, Копарска, Которска, Крагујевачка, Краљевачка, Крушевачка, Кумановска, Курска, Куршумлијска, Лајковачка, Лаповачка, Лебанска, Лесковачка, Лозничка, Маглајска, Мариборска, Мојковачка, Невесињска, Мостарска, Неготинска, Нишка, Новобрдска, Новопазарска, Новосадска, Ободинска, Обреновачка, Охридска, Пазинска, Паланачка, Панчевачка, Параћинска, Праховска, Прешевска, Прибојска, Призренска, Пријепољска, Приштинска, Прокупачка, Ражањска, Сврљишка, Сарајевска, Сињска, Сјеничка, Скадарска, Скопска, Смедеревска, Сокобањска, Солунска, Сомборска, Сплитска, Србињска, Суботичка, Теслићка, Тетовска, Требињска, Трстеничка, Тутинска, Ћупријска, Ужичка, Улиињска, Цариградска, Цетињска.Црнотравска, Чањска, Чачанска, Шабачка, Штипска. 
Б) Ходоними са комонимом: Белољинска, Белотиначка, Бербатовачка, Бериљска, Бољевачка, Бреничка, Брестовачка, Бујмирска, Габровачка, Велепољска, Вукмановска, Вучјанска, Горњоадровачка, Горњоматејевачка, Граховачка, Габровачки пут, Делиградска, Добродолска, Дољевачка, Доњовлашка, Доюоматејевачка, Дреновачка, Дубравска, Душничка, Јасеновачка, Јошаничка, Јелашничка, Калетиначка, Каменичка, Каменички пут, Кнежсичк, Коритничка, Крављанска, Крајковачка, Кумровачка, Куновичка, Кутинска, Лалиначка, Лепајска, Липовачка, Луковска, Малчанска, Матејевачка, Матејевачки пут, Медочевачка, Мердарска, Мерочинска, Мраморска, Новоселска, Облачинска, Орашачка, Паљинска, Партизанских вода ${ }^{3}$, Пасипољански пут, Перутинска, Поповачка, Проломска, Рударска, Рујничка, Рибарска, Сечаничка, Сопотничка, Суводолска, Суповачка, Таковска, Топничка, Трнавска, Трупалска, Ћурлинска, Хумска, Хусињска, Церјанска, Чајетинска, Чајничка, Чамурлијска, Чокотска.

\section{3. Ороними као мотивациони елемент нашли су се у следећим нишким ходонимима:}

Авалска, Биоковска, Бјеласичка, Бјелашничка, Бубағска долина, Буковичка, Велебитска, Великојастребачка, Гајтаничка, Горичка, Гочка, Грмечка, Дели Јована, Делијска, Динарска, Дурмиторска, Бердапска, Зеленгорска, Зелени врх, Златарска, Златиборска, Иванковачка, Игманска, Јастребачка, Јахоринска, Јеличка, Кабларска, Кадиғача, Кајмакчаланска, Каменички вис, Карпатска, Козарачка, Копаоничка, Космајска, Љубићска , Ловћенска, Малојастребачка, Мирочка, Мишарска, Овчарско-кабларска, Овчепољска, Озренска, Опленачка, Пасјачка, Похорска, Раданска, Романијска, Ртањска, Селичевица, Сићевачка, Старопланинска, Стражиловска, Сувоброска, Сувопланинска, Триглавска, Фрушкогорска, Церска, Чакорска, Чегарска, Чемерничка, Шарпланинска, Широке падине, Шуматовачка.

Највећи број оронима су они који се налазе у Србији и они чине $71 \%$ свих ходонима оронимске мотивације, док се остали ороними налазе у Босни и Херцеговини, Црној Гори, Хрватској, Словенији, Грчкој, а два оронима су међународног карактера.

\section{4. Хидроними у нишким ходонимима обухватају 31 реку (име Нишава јавља се у два ходонима), 3 језера и 1 море. \\ Бегејска, Бистричка, Бованска, Брегалничка, Вардарска, Ветерничка, Височка, Врбаска, Дојранска, Дринска, Друга Нишавска, Дунавска, Зетска, Ибарска, Јабланичка, Јадранска, Јужноморавска, Колубарска, Косаничка, Лабска, Лепеничка, Лимска, Мора-}

\footnotetext{
${ }^{3}$ Овај ходоним је вероватно настао по селу Партизанске Воде на Златибору, које је некада било Кулашевац, а сада Златибор.

${ }^{4}$ У вези са ходонимом Љубићска могу се истаћи две чињенице. Прва је формалне природе и односи се на правописно решење овог имена улице, у којем се не запажа упрошћавање сугласничке групе којим би требало да се дође до облика Љубићка, јер се сугласник $\hbar$ нашао испред суфикса -ски (Правопис 2010: 43-44). Етиологија овог ходонима није лако разрешива будући да постоје најмање две могућности подстицаја именовања ове улице. Према поменутом извору грађе за овај рад (Станисављевић/Димитријевић 2018), ова улица је добила име према градској четврти у Чачку. Међутим, вероватније је да се ради о брду Љубић код Чачка на којем је одиграна Битка на Љубићу 1815. године у току Другог српског устанка. Не треба занемарити још једно могуће семантичко порекло овог ходонима - презиме Љубић.

У овом раду ходоним Љубићска придружен је групи са оронимом у имену.
} 
вичка, Моравска, Неретвљанска, Нишавска, Расинска, Преспанска, Пусторечка, Савска, Ситничка, Струмска, Сутјеска, Тимочка, Топличка, Унска.

2.5. Хороними као мотиватори у нишкој ходонимији показали су се 30 пута и то као природни и административни хороними.

А) Природни хороними саставни су елементи имена 23 улице:

Балканска, Банатска, Босанска, Власинска, Војвођанска, Гружанска, Далматинска, Драгачевска, Добричка, Жупска, Заплањска, Крајинска, Личка, Лужничка, Мавровска, Мачванска, Посавска, Приморска, Сремска, Тиквешка, Херцеговачака, Хомољска, Шумадијска.

Б) Административни хороними мотивација су код 6 ходонима и 1 агоронима:

Византијски булевар, Грчка, Јерменска, Кубанска, Римска, Франиуска, Црногорска.

2.6. Градске четврти су у широкој употреби у говору Нишлија. Становници се међусобно препознају, групишу и процењују према четврти у којој живе, па се може рећи да су ова имена средство доказивања неке врсте друштвеног престижа. Имена градских четврти су саставни делови следећих ходонима:

Апеловач, Ардијска, Брзобродска, Бубањска, Виник, Виничка, Врежинска, Габровачка река, Делијски вис, Доюоврежинска, Дурлан, Јагодинмалска, Кованлучка, Колонија ЕИ, Калач брдо, Криви вир, Криве ливаде, Ледена стена, Палилулска, Пантелејска, Нова железничка колонија, Расадник, Синдикални станови, Стара железничка колонија, Црвена звезда, Чалије.

2.7. Микротопоними су већим бројем из ближе или даље околине Ниша, мада се може наићи на топоним који се налази у некој другој земљи. Ово се односи на Зејтинлик у Грчкој, а свакако не на швајцарски ојконим Женева, јер се у овом случају ради о излетишту код Нишке Бање.

Градска, Градскопољска, Делничка, Беренска, Женевска, Зејтинличка, Изворска, Јасенове воде, Калничка, Кладеначка, Ливадска, Ложионичка, Новоградска, Обалска, Пољска, Парка пријатељства, Рудничка, Сточни трг, Тврђавска, Хиландарски метох, Чаирска.

У оквиру ове подгрупе издвојени су микротопоними којима се именује археолошко налазиште: Булевар Медијана, Гамзиградска, Медијана.

2.8. Имена манастира и цркава су инспирисала номинацију 11 нишких улица. Овде су се нашли познати српски манастири и цркве као што су Грачаница, Дечани, Жича, Крушедол, Милешева, Раваница, Студеница, Хиландар, али се могу препознати и мањи, локални као што су Ајдановац (манастир у Топлици испод Јастрепца), нишка црква Св. Николе и манастир Св. Тројице у селу Габровцу. 
Ајдановачка, Грачаничка, Дечанска, Жичка, Крушедолска, Манастирска ${ }^{5}$, Милешевска, Раваничка, Светониколска, Студеничка, Хиландарска.

2.9. У именима нишких улица нашла су се четири острва, од којих је једно, заправо, секундарни хрононим - Крp, а остала три су јадранска острва, односно, топоними са подручја бивше Југославије.

Брачка, Крфска, Лочињска, Хварска.

2.10. Најпродуктивнији тип ходонима топонимске мотивације је онај са ојконимом као основним структурним елементом. Таквих ходонима има $49,21 \%$. За овом групом следи оронимски тип ходонима са $16,32 \%$ заступљености. Остали типови ходонима појављују се у много мањем броју: са хидронимом у имену има $9,47 \%$ ходонима; са хоронимом $7,63 \%$; са именом градске четврти $6,84 \%$; са микротопонимом 6,58\%; са именом манастира или цркве $2,89 \%$ и са именом острва $1,05 \%$ ходонима топонимског именовања. Удео сваког од наведених типова представљен је у дијаграму.

\section{Дијаграм 1. Удео топонимских типова у нимкој ходонимији}

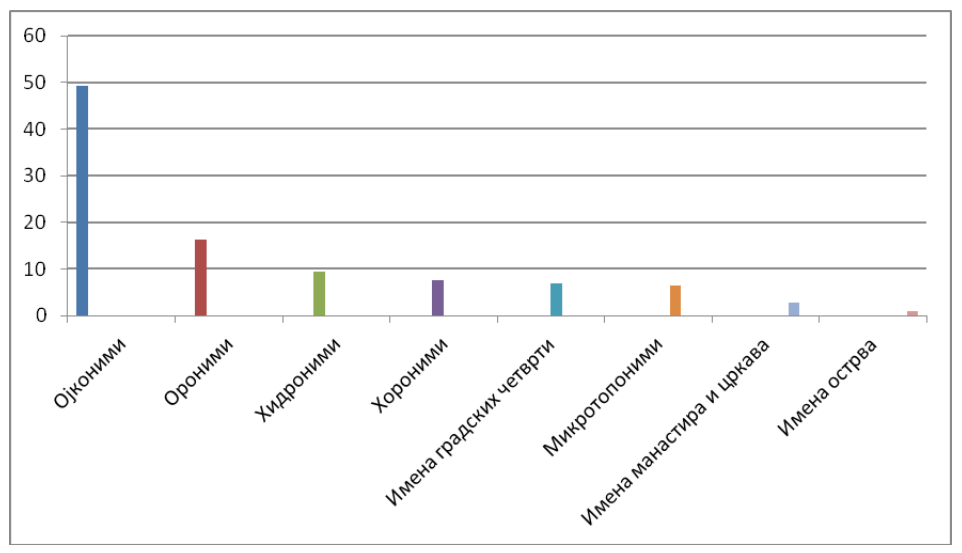

2.11. Анализом географског порекла топонима, који чине саставни елемент нишких ходонима, долази се до закључка да је највећи проценат ходонима мотивисан топонимом који се налази у Србији и њих има 72,63\%. Интересантно је да велику фреквентност показују ходоними са топонимом који се налази у земљама бивше Југославије. Таквих има $21,05 \%$ свих анализираних ходонима. Високу продуктивност показују астионими из земаља бивше Југославије (50\% од укупног броја топонима са овог подручја), а за њима следе ороними (20\%),

\footnotetext{
${ }^{5}$ Ова улица налази се у насељу Габровачки пут па је вероватно по манастиру у Габровцу посвећеном Св. Тројици.
} 
затим хидроними (13,75\%), док су остали топоними мање заступљени. Од свих ходонима са топонимом из бивше Југославије, 33,78\% потиче из Босне и Херцеговине, док је мање из осталих држава: Македонија 20,27\%, Хрватска $20,27 \%$, Црна Гора $18,92 \%$, Словенија $6,76 \%$. Сигурно је да оваква статистичка слика јасно говори о још увек чврстим везама Србије и осталих земаља које су некада чиниле једну државу, без обзира на сва несрећна дешавања која су се одигравала нарочито деведесетих година прошлог века. Изгледа да ни ратовања нису утицала да се у Србији измени однос према становницима осталих бивших југословенских република, а било би интересантно овакве податке упоредити са стањем у тим садашњим државама.

Учешће топонима из осталих земаља је незнатно. Ради се углавном о државама са којима се Србија граничи или се налазе у близини (Бугарска, Грчка, Албанија), а изузетно о неким удаљенијим (Француска, Русија, Јерменија, Куба) или чак о државама које данас постоје само на страницама историје (Византија, Рим као Римско царство). Постоје и међународни топоними, под чим се овде подразумевају топоними који се простиру на територији две или више земаља (нпр. Карпати). Оваквих мотивационих типова (светских и међународних) има 24 , односно $6,32 \%$ у укупном ходонимском збиру.

\section{Дијаграм 2. Ходоними топонимске мотиваџије према географском пореклу топонима}

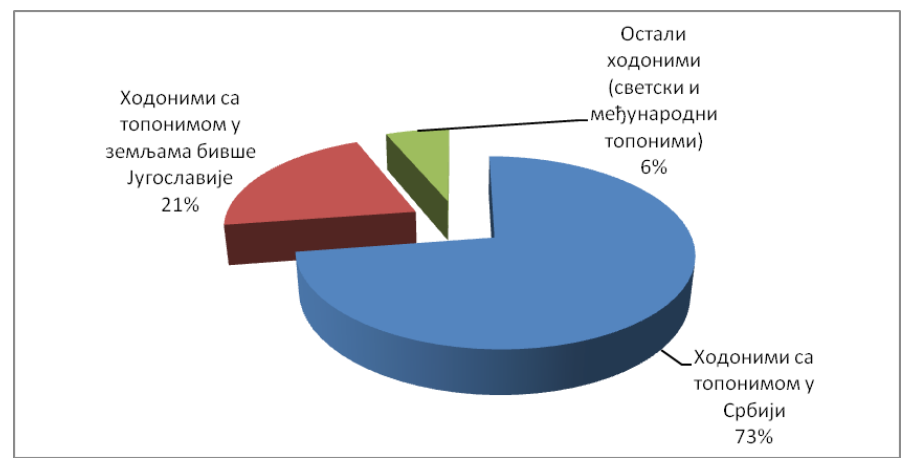

2.12. Група ходонима мотивисаних топонимима из Србије показује да су поједини мотивациони модели продуктивнији од других. Као семантички елемент ходонима најчешће се јавља неки ојконим (50\%) и скоро подједнако су заступљени астионими и комоними. Оронима има у 17,03\% обухваћених ходонимских јединица. За овим двема групама следе у мањем проценту: имена градских четврти $(9,42 \%)$, хидроними $(7,61 \%)$, микротопоними $(7,25 \%)$, хороними $(5,07 \%)$, имена манастира и цркава $(3,62 \%)$. 
Дијаграм 3. Ходоними топонимске мотивације према врсти топонима са подручја Србије

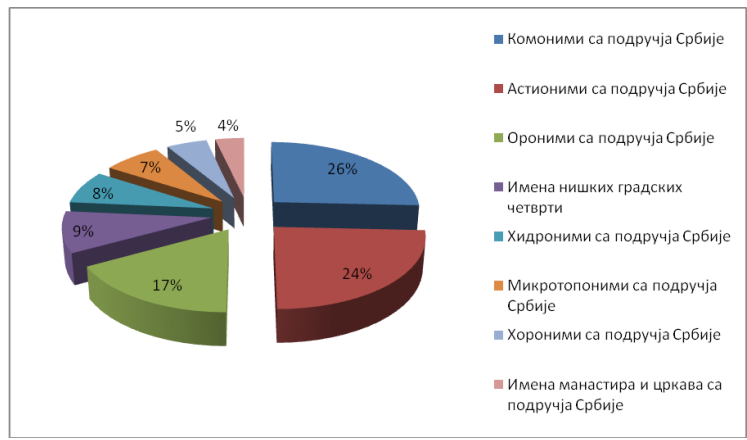

На основу анализе фреквентности појединих топонима јасно је да одређена врста топонима има превагу у односу на све остале. Процентуални удео се поклапа са другом врстом топонима у групи ходонима који садрже топоним са подручја бивше Југославије. Најчешћи мотиватори нишких ходонима јесу ојконими. Наиме, у групи ходонима са топонимима из Србије $50 \%$ је оних који садрже ојконим, а у групи ходонима са топонимом из регије бивше Југославије $50 \%$ су ходоними који садрже астионим. Заправо, ради се о истој врсти топонима, с тим што су астионими из бивше Југославије видно садржани у структури нишких ходонима. Међутим, то се не односи и на комониме, којих има у запаженом броју, али географског порекла из Србије. Иначе, ојконими су категорија која заузима 49,21\% целокупног фонда ходонима топонимске мотивације, што подразумева укупно 112 астионима и 75 комонима, односно 187 ходонима са ојконимом као саставним елементом. Међутим, када се ови ходоними сагледају из угла географског порекла, долази се до закључка да велики број астионима потиче из Србије (67 астионима, односно 59,82\% од укупног броја астионима), а комоними су у највећем броју са подручја Србије (94,67\% од укупног броја комонима). Овако неједнак однос учешћа астионима и комонима из Србије и из региона бивше Југославије долази отуд што се имена села у ходонимима обично јављају као места која се налазе у ближој или даљој околини града и врло често се пружају правцем у којем се налази наведено село у односу на град. То би значило да запараво и не постоји оправдан разлог да се помињу комоними који се налазе ван подручја општине или области у којој се налази сам град, једино уколико разлог није историјски. У случајевима хрононимске мотивације, чак се и село изван граница земље може наћи у ходониму неког града. Такав случај су свакако ретки комоними нишке ходонимије: Јасеноваи, Кумровец, који су се нашли у ходонимима Јасеновачка и Кумровачка. 
2.13. Од осталих мотивационих типова топонимима са подручја бивше Југославије, након ојконима, велику продуктивност показују ороними (20\%), затим, хидроними (13,75\%), док су други топоними у мањој мери подстицали именовање нишких улица: хороними $(6,25 \%)$, имена острва $(3,75 \%)$ и микротопоними $(1,25 \%)$.

Дијаграм 4. Ходоними топонимске мотивације према врсти топонима са подручја бивше Југославије

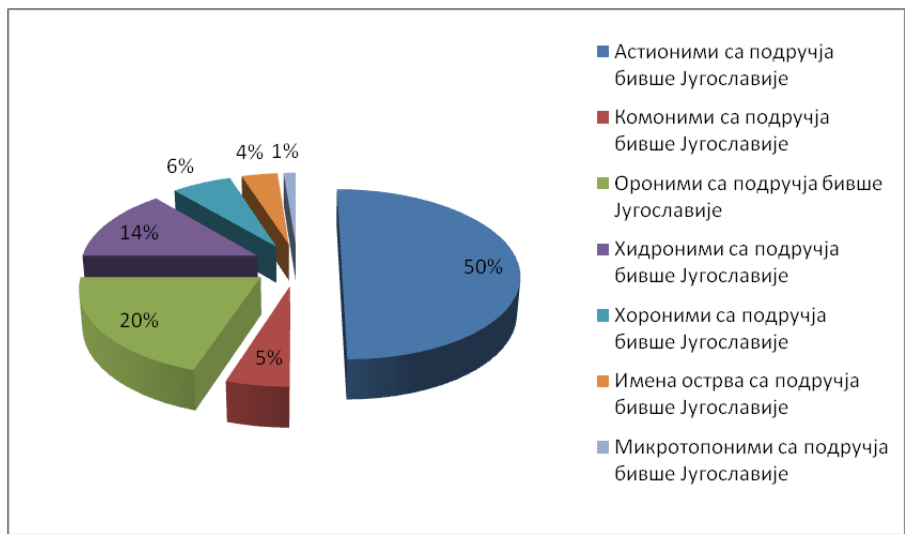

2.14. Уколико се ходонимска структура сагледа из граматичког угла, најпре треба истаћи елиптичну форму ходонима насталу сажимањем двочланог имена из којег је елиминисан урбонимни термин улица, док је детерминатор из првог дела имена задржан, што је неретка појава у ходонимији уопште. Једини примери у којима су сачувани урбонимни термини чак и у неформалној комуникацији јесу: Булевар Медијана и Византијски булевар. Први члан, осамостаљени детерминатор, најчешће се налази у облику присвојног придева. Мањи је број ходонима исказаних именицом или синтагмом у номинативу једнине или множине. Најмању продуктивност имају ходоними исказани формом посесивног генитива.

2.14.1. Ходоними исказани присвојним придевом чине 92,37\% целокупне грађе. Овој групи припадају сви ојконими, сва имена манастира, цркава и острва, као и највећи део оронима, хидронима, микротопонима, а мање је оних са именом градске четврти.

2.14.2. Видно мањи број ходонима је у номинативној форми. Њих 26, односно 6,84\%, припада овој групи. Међу њима је највише имена четврти (чак 16 од свих 26 ходонима мотивисаних именом четврти); следе ходоними оронимске, микротопонимске и хидронимске мотивације: Апеловац, Бубағска 
долина, Булевар Медијана, Виник, Габровачка река, Делијски вис, Дурлан, Зелени врх, Јасенове воде, Кадиьача, Калач брдо, Каменички вис, Колонија ЕИ, Криве ливаде, Криви вир, Ледена стена, Медијана, Нова железничка колонија, Расадник, Селичевица, Синдикални станови, Стара железничка колонија, Сточни трг, Сутјеска, Хиландарски метох, Црвена звезда, Чалије.

2.14.3. Само три ходонима се налази у облику посесивног генитива, што је 0,79\% свих анализираних ходонима: Дели Јована, Парка пријатељства, Широке падине.

2.14.4. Оваква фреквентност појединих типова ходонима према структури односи се на ходониме топонимске мотивације и вероватно је да се неће поклопити са анализом ходонима антропонимске мотивисаности (која је остављена за неку другу прилику). Поломац је у београдским ходонимима антропонимског порекла пронашао највећи број ходонима исказаних посесивним генитивом (Поломац 2013).

Статистичка заступљености модела ходонима према структури представљена је у дијаграму.

\section{Дијаграм 5. Ходоними Ниша топонимске мотиваџије} према структури

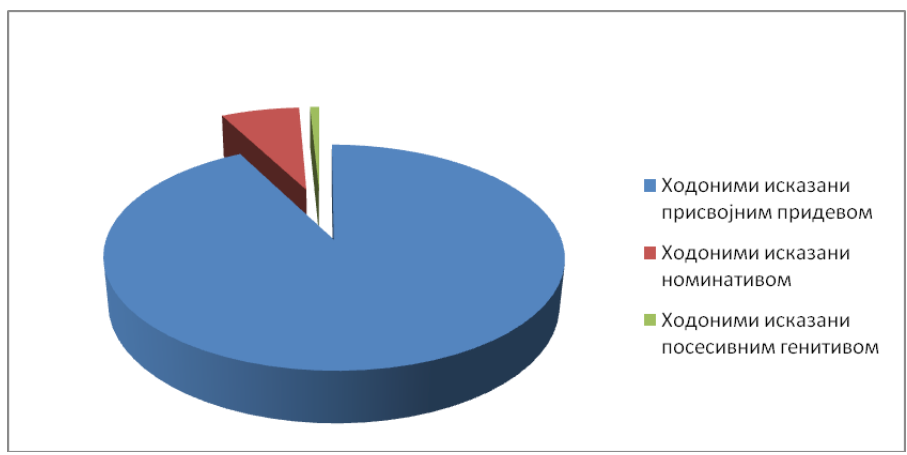

\section{3. ЗАКЉУЧНЕ НАПОМЕНЕ}

3.1. Након мотивационе и структурне анализе нишких ходонима топонимског именовања и утврђивања заступљености појединих типова, дошло се до следећих битнијих закључака:

- Од 1.463 нишке улице, 25,97\% је именовано неким топонимом.

- Највећи број ходонима мотивисан је ојконимом (49,21\%), а најмањи именом острва $(1,05 \%)$. 
- Највише ходонима мотивисано је топонимом са подручја Србије $(72,63 \%)$.

- Топоними са подручја бивше Југославије нашли су се у $21,05 \%$ анализираних нишких ходонима, а најпродуктивнији су они из Босне и Херцеговине $(33,78 \%$ свих ходонима са топонимом из бивше Југославије).

- Најфреквентнији структурни тип обрађених ходонима је форма исказана присвојним придевом (92,37\%).

3.2. Ходоними као специфична врста топонима не показују спонтаност у именовању као што је то случај са већином топонима. Код њих углавном нема реалне мотивације приликом надевања имена, јер је главни и једини фактор у избору човек и његове склоности, опредељења и лични избори. Међутим, иако најчешће појединац одлучује у избору ходонима, тај урбани именослов свакако је одраз духа тога града, његове историје и нарочита слика његових становника. Нишки ходоними топонимске мотивације говоре о привржености топонимији Србије, али и о јаким везама са некадашњим југословенским републикама, те нас нишки ходоними подсећају на некадашње југословенство. Судећи по њима, Нишлије се најбоље сећају оронима, хидронима, астионима из Босне и Херцеговине, али се труде да на овај начин испоштују и остале ближе и даље суседе Србије.

\section{ЛИТЕРАТУРА}

Безлај 1983: Ф. Безлај и др., Основен систем и терминологија на словенската ономастика, Скопје: Македонска академија на науките и уметностите.

Лађевић 1984: М. Лађевић, Прилог проучавању нишке ходонимије, Ономатолошки прилози, V, 217-228.

Подољска 1978: Н. В. Подольская, Словарь русской ономастической терминологии. Москва: Академия наук СССР, Институт языкознания издательство „Наука”.

Поломац 2013: В. Поломац, Савремени београдски ходоними антропонимског порекла. Acta onomastica, LIV, 228-242.

Правопис 2010: М. Пешикан и др., Правопис српскога језика, Нови Сад: Матица српска.

Ракић 2011: Виолета Ракић, Називи улица у Новом Саду: nomen est omen, у: В. Васић, Г. Штрбац (ур.), Говор Новог Сада. Морфосинтак- 
сичке, лексичке и прагматичке особине, Нови Сад: Филозофски факултет, 549-568.

Рељић 2016: Митра Рељић, О савременим косовскометохијским ходонимима (социолингвистички аспект), Јужнословенски филолог, LXXII, $1-2,139-157$.

Станисављевић/Димитријевић 2018: Живојин Станисављевић, Милан Димитријевић, Улице и тргови града Ниша, Ниш: Удружење стваралаца Ниша „Цар Константин”.

Шћепановић 1997: Михаило Шћепановић, Ономастичка терминологија и норма, у: Милосав Бабовић (ур.), Трећи лингвистички скуп „,Бошковићеви дани”, Подгорица: Црногорска академија наука и умјетности, 14, 215-221.

\section{HODONIMS OF NIŠ WITH TOPONYMS MOTIVATION}

\section{Summary}

This paper presents the onomastic analysis hodonims of Niš with toponyms motivation. The methods used in the work are: corpus, analytical, descriptive and comparative and aim is to determine which types of toponyms participate as motivators in the nomination of Niš streets. Hodonims are also interpreted from a structural angle in order to determine the most productive form. Quantitative analysis of the material led to conclusions about the frequency of individual hodonims types. Motivation with the oikonyms from the territory of Serbia has shown high frequency, and the form shown by the posesive adjectives most often used in the hodonims of Niš.

Key words: Serbian language, onomastics, hodonymy, toponymy, Niš.

Tatjana G. Trajković 